||||||||||||||||||||||||||||||

製品紹介

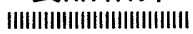

\title{
新合繊 ゆかた「モア・バカンス」
}

\section{1.はじめに}

「浴衣」（ゆかた）は，用途上区分された和服の一 形態であり, 昔上流社会の人が入浴 (蒸し風呂) や 行水するときに用いた湯帷子（ゆかたびら）が語源 とされている.

日本の民族衣装である和服，すなわち「きもの」 の始まりは, 藤や麻などの植物を煮たり, 蒸したり, 吒いたりして繊維質を取り出し, 糸を作った弥生時 代といわれている. この頃に最初のきむのである荒 い麻の糸で織った布の中央に頭が通る丸い穴を開け て着る「貫頭衣」（かんとうい）が現れる.

大和時代には, 古墳から出土した人物埴輪にある ような「胡服」(こふく), また奈良時代には高松塚 古墳の壁画に見られるようなひだのある長い裳 （あ）に, 細い紐状の帯といった大陸からの影響を受 けた衣裳となる。

宮中における女性の礼装であった平安時代の「十 二単」(じゅうにひとえ) から, それまで下着だった 「示袖」が表着として衣服の中心になった鎌倉時代 を経て安土桃山時代に定着し, 現在の着物の原型が 確立している.

江戸時代の「振り袖」「羽織」, 大正時代の「訪問 着」, 昭和初期の丸帯など伝統を受け継ぎながら時 代のニーズに応え, 少しずつ着物も変化して今日に 至っている.

\section{2. 和装分野の国内消費動向}

和装品には, 振り袖・訪問着・付下げ・小紋など の着尺, 長襦衼, 帯, ゆかた, 帯揚げ・帯締め・伊

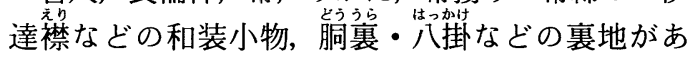
る.

\section{渡辺}

消費量の多い品目は, 着尺地を筆頭に, 帯, 裏地, ゆかた，長襦袢，小物の順となっている.

これら和装品の消費量は，1985年から1995年の10 年間で 20990 トンから13787トンへ $34 \%$ と大きく減少 している.

素材別では, 絹の消費量は13253トンから7670ト ンへ $42 \%$ 減少し, ポリエステルフィラメントでは 1952トンから1291トンへ34\%の減少である.また, その他の素材でも減少傾向にある.

1985年度統計で, 和装全体に占める絹の消費量比 率は63\%，ポリエステルフィラメントが $9 \%, 1995$ 年度では, 絹が $65 \%$, ポリエステルフィラメントが $11 \%$ て 絹が圧倒的比率を占めている. 特に, 和装 の主力品目の着尺においてポリエステルの比率は $8 \%$ と低い.

なお, 数量でポリエステルフィラメントの比率が 高い品目は, 長襦衼 $28 \%$, 裏地 $21 \%$, 小物 $17 \%$ であ る.

ところで, 今の若い女性が「きもの」に対してど う考えているのかインタビューした結果では,

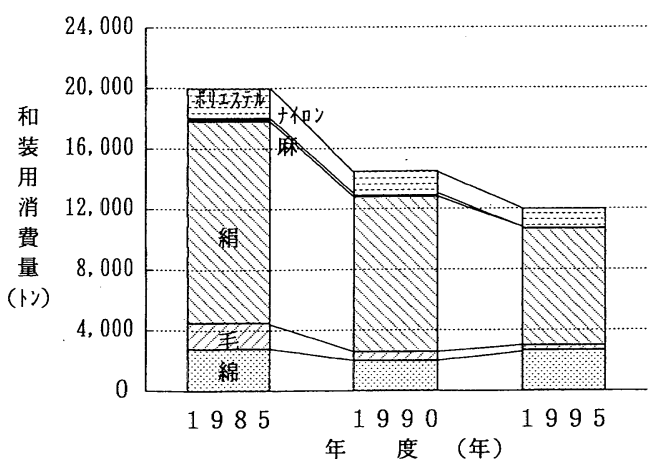

図 1 和装消費量推移 

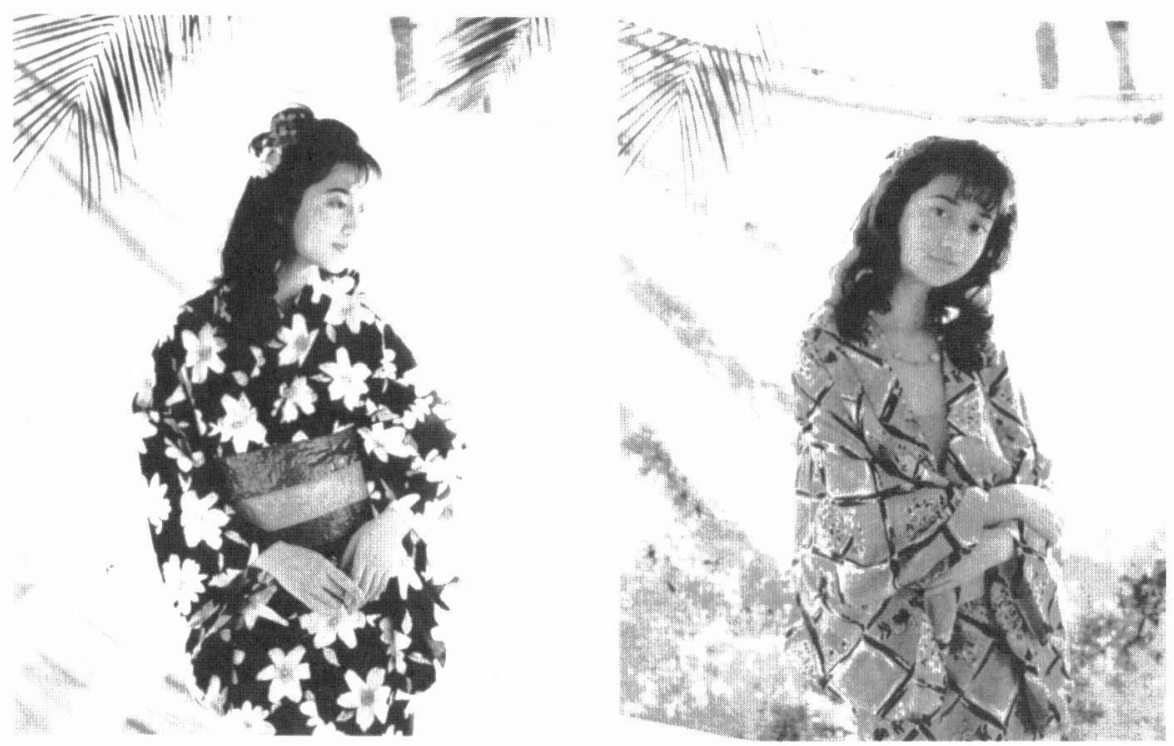

'図2「モア・バカンス」

(1)日本人が作った代表的な文化のひとつ

(2)日本人を意識でき，アイデンティティを表現でき る衣裳

(3)きむのは, 日本人として大切にしなければならな い文化

(4)きものを着るといつもの自分と違う自分に逢える (5)きものを着ると, 目立つし, 注目される.また, それ以上に心を豊かにしてくれる

など「きむの」への関心の高さが浮き彫りにされた。

しかし，これほどの高い関心を消費者が持ちなが ら, 着用実態や消費実態が低迷状況のままである要 因には，伝統的「きもの」があまりにも高額化， フ
オーマル化してしまったために，

(1)買えない

(2)着られない

(3)着ていく場所がない

(4)しきたりがあって，自分で選べない

(5)着ても動けない，食べられない，污れに気をつけ なければならないなど窮屈

(6)手入れや保管も大変

など近づきたくても近づけないヤング層を「き屯 の」から遠ざけてきたことにあると考えられる.

表 1 浴衣の国内消費量（単位：トン）

\begin{tabular}{|c|c|c|c|c|c|c|c|}
\hline \multirow{5}{*}{$\Phi$} & 織 維 区 分 & 平成 2 年 & 平成 3 年 & 平成 4 年 & 平成 5 年 & 平成 6 年 & 平成 7 年 \\
\hline & 天 然繊 維 & 1,441 & 1,470 & 1,500 & 1,316 & 1,215 & 1,215 \\
\hline & 綿 & 1,441 & 1,470 & 1,500 & 1,316 & 1,215 & 1,215 \\
\hline & 毛 & 0 & 0 & 0 & 0 & 0 & 0 \\
\hline & 絹 & 0 & 0 & 0 & 0 & 0 & 0 \\
\hline \multirow[t]{2}{*}{ か } & 麻 & 0 & 0 & 0 & 0 & 0 & 0 \\
\hline & 化 緎 & 0 & 0 & 0 & 0 & 0 & 0 \\
\hline \multirow{4}{*}{ た } & 合成繊 維 & 11 & 11 & 9 & 8 & 6 & 6 \\
\hline & +1 ㄴ & 0 & 0 & 0 & 0 & 0 & 0 \\
\hline & ポリエステル & 0 & 0 & 2 & 3 & 2 & 2 \\
\hline & 合計 & 1,452 & 1,481 & 1,509 & 1,324 & 1,221 & 1,221 \\
\hline
\end{tabular}




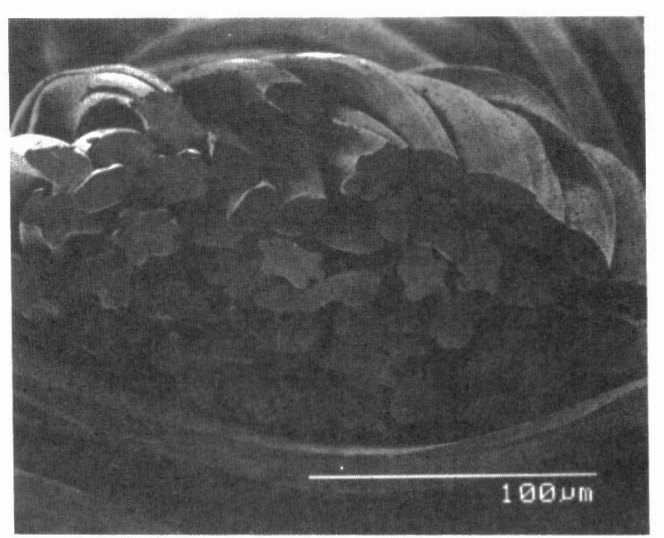

困 3 “CEO- $\alpha$ ” 断面写真

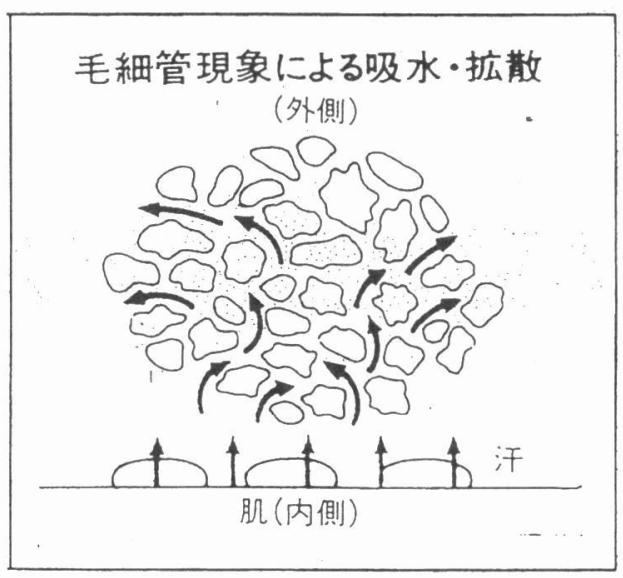

図 4 “CEO- $\alpha ”$ の吸水・拡散

\section{3. 快適新合繊ゆかた}

3.1 「ア・バカンス」

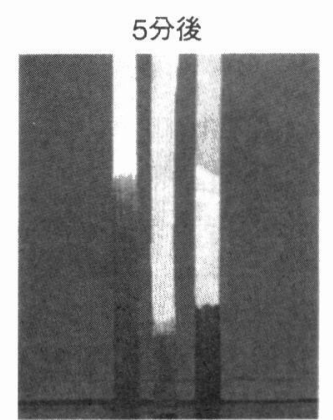

A B C

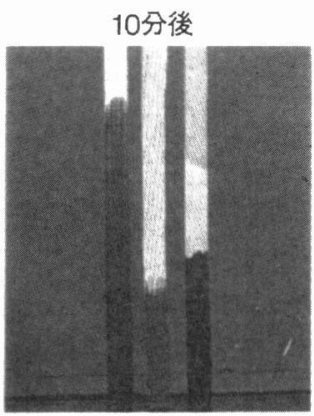

A B C

*A-CEO $\alpha$ B-従来のボリエステル C-綿

JIS L1096 (一般織物試験方法)

TRS 1084 A

図 5 吸水・吸汗の比較テスト（バイレック法）

そんなヤング層を対象に，東レ(株が業界では初め ての快適新合繊（ポリエステル100\%）による次世代 「ゆかた」素材を開発した. 綿素材の独壇場であった 従来の「浴衣」とは一線を画する屯ので, 湯上がり の着物というイメージではなく,「夏の新しいキモ ノファッション」を「モア・バカンス」と名づけ, 若い女性を対象に1995年 1 月から展開している.

発表以来, 各種マスコミにも取り上げられ業界や 店頭での消費者からの評判む良好である.

販売量は初年度で 5,000 着, 平成 9 年度で 60000 着.

\section{2 従来の浴衣素材}

従来の浴衣素材は, 綿が99.5\% と圧倒的な比率を 占め, 合繊素材はわずかに $0.5 \%$ である.

しかし, 綿の浴衣は,

(1)家庭洗濯ができないことの経済性も含めた不便さ

(2)シワが回復しないことでの動きにくさ

表 2 乾燥速度

\begin{tabular}{c|c|c|c}
\hline \hline \multirow{2}{*}{$\begin{array}{c}\text { 乾燥時間 } \\
\text { (分) }\end{array}$} & \multicolumn{3}{|c}{ 乾燥率 $(\%)$} \\
\cline { 2 - 4 } & CEO- $\alpha$ & 従来のポリエステル & 綿 \\
\hline 0 & 59.7 & 59.7 & 0.9 \\
\hline 10 & 83.4 & 82.7 & 28.3 \\
\hline 20 & 98.8 & 98.2 & 52.6 \\
\hline 25 & 100 & 100 & 75.7 \\
\hline 60 & & & 96.9 \\
\hline 120 & & & 97.2 \\
\hline 240 & & & 97.6 \\
\hline
\end{tabular}

・脱水 10 秒後のデータ

・乾燥率とは、含水率から求めた逆数 


\section{(3)素材への飽き}

などの問題点があり，消費者に敬遠されがちである．

\section{3 快適新合繊ゆかたの特徴}

これらの欠点を解消できる快適新合繊 “CEO- $\alpha$ ” を新しいゆかた素材として提案した，植物の毛細管 吸水構造をヒントに設計された “CEO- $\alpha ”$ は, ミク ロンレベルの微細な溝を持つ異型断面の糸之, 丸い 断面の系をランダムに配列し，ねじれを与えている，

この微細な溝, スキマ構造, ねじれによって綿以 上の吸汗性能を実現したことで, 汗をすばやく吸水 し, ベトつきのない, 爽やかな着心地を作る.

また，吸い取られた汗は，生地全体にサッと広が り空気中に拡散される.この速乾性は, 洗濯の時に あ効果を発揮し，乾きがとてもスピーディーである.

さらに, 乾燥時間が短ければ短いほど, 菌の繁殖 あしにくく，より清潔に保つことができる.

ポリエステルの特徴であるウォッシュ＆ウェア性 と防シワ性を持った “CEO- $\alpha$ ” は, 形態安定性にあ 優れ家庭でも手軽に丸洗いができ，洗濯した後も， 一アイロンで着用でき，洗濯での色落ちの心配むほ とんよ゙ない。

また，“CEO- $\alpha ”$ のユニークな繊維構造による独 特のシャリ感が, 綿にはない肌離れの良さを実現した。 実際に当社テクノラマ人工気象室で着用テストを 行った結果は以下の通りである.

A. 実験水準

\begin{tabular}{c|c|c|c}
\hline \hline No & ゆかた & インナー & 帯 \\
\hline 1 & モアバカンス & ゆかたインナー & 半幅ゆかた帯 \\
\hline 2 & 綿 & ゆかたインナー & 半幅ゆかた帯 \\
\hline
\end{tabular}

B．テクノラマ環境条件

室温 $25^{\circ} \mathrm{C}$

湿度 $65 \%$

C. タイムスケジュール

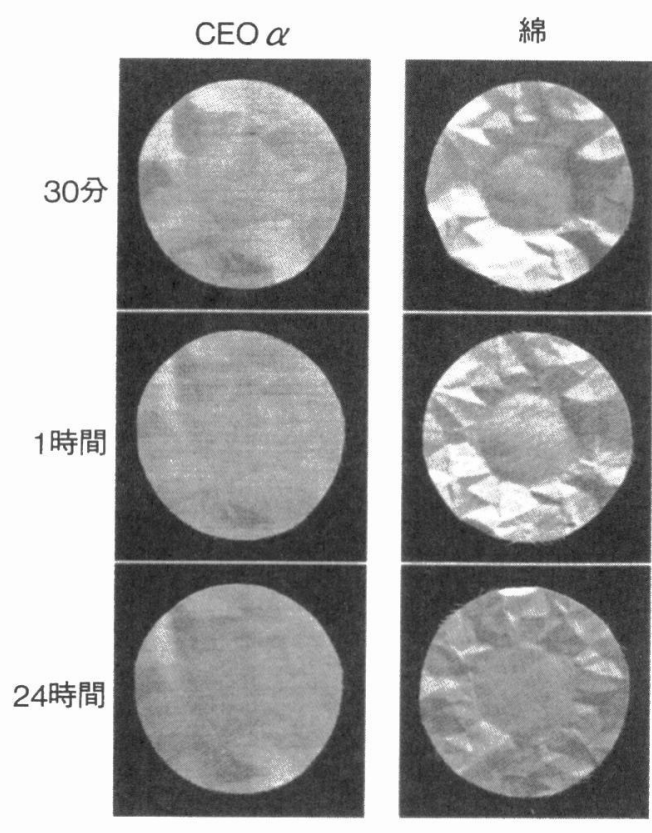

図 6 詰め込み法によるシワ回復テスト

表 3 形態安定性（洗濯 5 回後）

\begin{tabular}{c|c|c}
\hline \multirow{2}{*}{} & \multicolumn{2}{|c}{ 洗淮収縮旈（\%) } \\
\cline { 2 - 3 } & た て & 上 こ \\
\hline $\mathrm{CEO}-\alpha$ & 0.4 & 0.3 \\
\hline 綿 & 3.1 & 2.4 \\
\hline
\end{tabular}

\section{4.むすび}

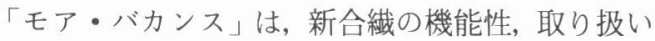
のしやすさ，色柄の豊富さなどの特徴で若い女性の 心をとらえ, 新合繊ゆかたの一大ブームを引き起こ した.

ゆかたを和装の入口として，また，良き日本文化 にふれる機会として，さらに，自分を表現するファ ッションアイテムとして位置づけ，若者を対象とし

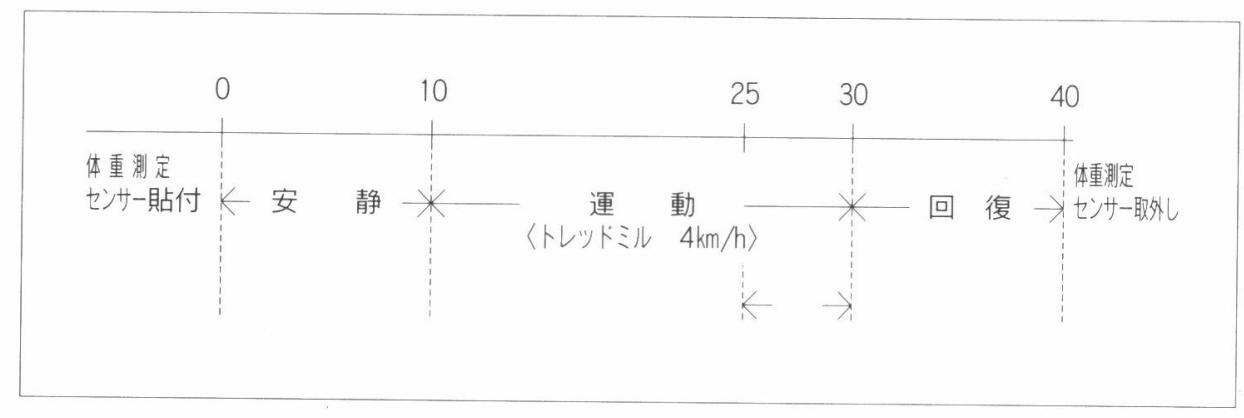




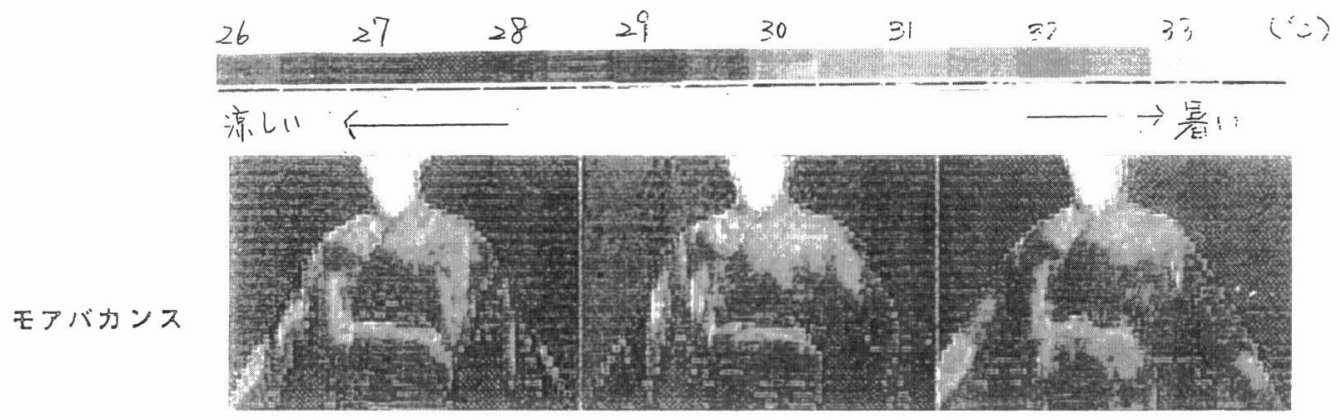

船

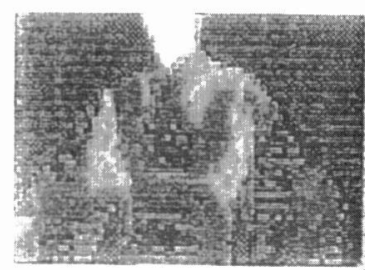

晏 静

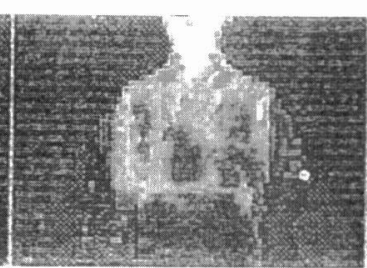

荤 動

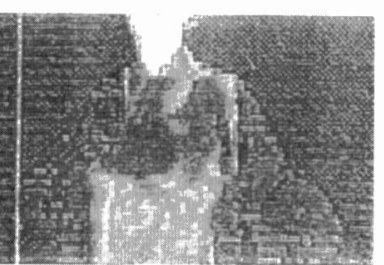

回 復

図 7 表面温度写真（サーマルイメジャ一）

たゆかた市場の開拓を行い，和装業界からも高く評 価されている.

「モア・バカンス」は今年の夏から男性用にも展 開を始め, カップルでさらに楽しめるようになっ た.

すでに展開している “STYLE de KIMONO”は, ダーツを入れたり, 襟や袖のカッティングを工夫 し，体のラインに自然にフィットするようにパター ン化された「きあの」である.

そのため, 夕オルやさらしで体を補正する必要む なく, 腰紐 2 本を使って自分で着用でき, 長時間で も美しいシルエットを保つことができる.

また, 襟元, 袖口, 裾などにアクセントカラーを 付けたり,きもの之同一素材で仕立てたリバーシブ ルの帯を結ぶことでコーディネイトしやすくしてい る.

洋服感覚で楽しく買える・着られる, しかもフォ
ーマルな場面にもマッチするような「きのもの需要 の創造」を課題に和装事業を積極的に消費者に訴求 し，展開していきたい.

\section{参考文献}

・日本のきもの, 京都きものコンサルタント協会編, 青桐社刊

・絹に関するノート, 米山達雄, 富民協会

- 衣料用及び家庭用繊維消費量調查 (内需要) 報告書, 日本化学 緘維協会

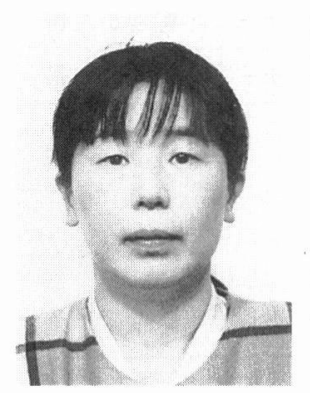

渡辺いく子（わたなべいくこ） 東レ(侏)キスタイル開発センタ 一第 3 開発室にてファッション テキスタイルの設計開発を担 当.（東レ(株テキスタイル開発 センター第 3 開発室, 干520-21 大津市大江 1-1-1, TEL. 077544-3525, FAX. 0775-43-2825) 